\title{
The Rationale for Applying Critical Pedagogy in Expanding Circle Countries: The Case of Iran
}

\author{
Ferdows Aghagolzadeh \\ Tarbiat Modares University (TMU), Tehran, Iran \\ Email: aghagolz@modares.ac.ir \\ Hossein Davari \\ Tarbiat Modares University (TMU), Tehran, Iran \\ Email: hdavari1358@yahoo.com
}

\begin{abstract}
The globalization of English in general and the global prevalence of English language teaching (ELT), as the most systematic way of English spread, in particular have led to a situation which has been debated and discussed from political, cultural, social and ideological standpoints. Since the early years of 1990s, following the publication of Phillipson's Linguistic Imperialism (1992), the appearance of a critical intellectual shift in applied linguistics has not only significantly challenged the mainstream ELT, but also has mostly introduced critical pedagogy (CP) as an alternative approach to the mainstream ELT especially in the Periphery. Thus, as ELT programs become more prevalent throughout the world, the cultural, political, social and ideological implications of this activity are more often debated and such considerations seem more relevant in societies that are culturally, politically, socially and ideologically are different from the Center and certainly the Iranian society as an Expanding Circle country in which English is taught as a foreign language and culturally, politically and ideologically is different from the Inner Circle Countries, is not an exception to this rule. This paper, as an attempt to review the current status of English and ELT in Iran, tries to deal with and introduce the strengths and benefits of CP as an alternative approach in ELT and moreover discuss the rationale for applying this approach with specific reference to the socio-political, cultural, ideological as well as educational features of the Iranian society. The writers strongly believe that, strengthening critical thinking in learners, empowering the learners to make them agents of transformation in the local and global arenas, unmasking the underlying values and ideologies of the mainstream ELT, and especially reducing the cultural and social implications of English in such societies involves rethinking the nature and status of ELT as well as resorting to $\mathrm{CP}$ as an alternative and effective approach in ELT.
\end{abstract}

Index Terms - critical pedagogy, mainstream pedagogy, English language teaching, expanding circle, Iranian society

\section{INTRODUCTION}

Pass all doubt, the increasing rise of English and the growing expansion of English language teaching (ELT) throughout the world have had some serious political, cultural, social, ideological as well as pedagogical consequences. Thus, it is not surprising that this unique position of English has some repercussions on the way it is seen, defined, presented, learned and taught and has led to a situation which has been discussed from political, cultural and social standpoints (see Block and Cameron, 2002; Brutt-Griffler, 2002; Canagarajah, 1999; Edge, 2006; Holliday 2005; Pennycook, 1994, 1998, 2001 and 2007; Phillipson, 1992 and 2009; Sharifian, 2009).

Not surprisingly, such a situation has led to some controversy and discussion surrounding ELT as the most systematic way of spreading English throughout the world. In Baladi's (2007) words, while teaching of English and English language itself have, for a long time, been seen as clean and safe exports, as a practical means of communication carrying few ethical implications, today there is a realization that teaching and spread of English involve complex moral, social and political implications. In a more precise word, although firstly the spread of English especially through ELT was considered as a purely instrumental advantage from Inner Circle countries (where English is generally the L1 including USA and UK) to Outer Circle countries (where English plays an institutional role as an L2 such as India and Singapore) and Expanding Circle countries (where English is learnt as a foreign language like China and Iran), at the same time raising some sensitivity, criticism and resistance has resulted in presenting some theoretical objections and critical theories and attitudes to English spread and ELT profession.

In Gray's (2002) words, contrary to the mainstream ELT pedagogy, its beliefs, practices and tenets, some notable critical attitudes have been raised in recent years mostly through an increasing wave of books, have been instrumental in stimulating a considerable degree of soul searching within ELT profession. In his opinion, what these works have had in common is a belief that the global spread of English is inherently problematic, inextricably linked to wider political issues and that ELT practices are neither value free, nor always culturally appropriate. Thus, it is not surprising to hear that the increasing ubiquity of English has aroused many reactions and raised many questions for those active in the 
field of applied linguistics. In fact, while the global spread of English, as Sharifian (2009) writes, has had serious ideological, socio-cultural, political, and pedagogical implications and consequences, has thoroughly been documented in a range of well-known publications, the appearance of new sets of questions and revised arguments and positions has been adding fuel to the debates. In this condition, specifically, as Anderson (2002) maintains, the appearance of the Phillipson's revealing and critical book entitled Linguistic Imperialism in the early years of 1990s was the beginning of forming an intellectual and critical shift in the conception of the global spread of English and such a shift is ongoing in the field of applied linguistics.

In this new critical shift, while Tollefson (1995), Tsuda (1997), Holborrow (1994) and Skutnabb-Kangas (1998) have mostly paid attention to the political, cultural and linguistic consequences of the global spread of English and the current status and role of this language throughout the world and less to the pedagogical implications of ELT, three other names, known as Phillipson's Children, namely Pennycook (1994, 1998 and 2001), Holliday (1994, 1997 and 2005) and Canagarajah (1999 and 2005) have tried to problematize more notably the current status and the increasing growth of mainstream ELT as well as the global spread of English.

In fact, the outstanding appearance of this critical shift in ELT not only has significantly challenged and complicated the mainstream ELT, but also has mostly introduced critical pedagogy (CP) as an alternative approach to the mainstream ELT. It is worth noting that although the incorporating critical pedagogy is more recent, it seems that it is going to find a notable position in the domain of applied linguistics. In the following, introducing the main components and features of this outstanding approach, we attempt to review its great potential and highlight the rationale and necessity of its application with specific reference to the Iranian society as an Expanding Circle country.

\section{REVIEW OF LITERATURE}

As noted, in the field of applied linguistics, the emergence of a prominent intellectual shift, involving some new trends, has led to viewing English and ELT through different critical paradigms. According to Davari (2011), Phillipson's Linguistic Imperialism (2002) was a milestone which has led to establishing a critical shift in applied linguistics and his ideas in this watershed work and others have invoked some notable scholars throughout the world in such a way that since 1992 many mainstream tenets and widespread beliefs in ELT have been challenged. According to Hall (2000), writers within the broad and somewhat diverse "critical pedagogy" such as Canagarajah, Pennycook and Phillipson have criticized the current view that sees the globalization of ELT as an inevitable, unproblematic and natural development. In his words, these writers accuse ELT of helping to maintain unequal Core-periphery relations in the capitalist world-economy and of suppressing diversity of language and thought.

Facing this situation, it is nothing to be surprised when Johnston (2003) writes that possibly the most significant development in ELT in the 1990s was the acceptance of this idea that ELT is and always has been a profoundly and unavoidably political activity. Akbari (2008a) also strongly maintains that education in general and ELT in particular is an activity filled with politics.

Reflecting the belief that education is never neutral and foreign language education has a political role to play in any educational system of the world (Byram and Feng, 2004), applying CP in ELT, as an approach to language education which places sociopolitical considerations high on the classroom agenda and incorporates a set of principles and practices that aim "not only to change the nature of schooling, but also the wider society" (Pennycook, 1990, p.24), can be introduced as an alternative approach in Outer and Expanding Circle countries especially those are culturally, politically, socially and ideologically different from or especially in contrast with the Inner Circle countries.

Having a look at the Iranian society as a member of Expanding Circe countries which is ideologically, culturally, politically and socially different from the two main representatives of the Inner Circle counties, namely USA and Britain, reveals that contrary to expectations, as Talebinezhad and Aliakbari (2003) maintain, English seems to have smoothly found its way to the heart of Iranian society. In other words, it appears that the Iranian society is no exception to the worldwide trend of English being learned more widely. Moreover, as big business, English is the most commonly taught foreign language in this society both in public and especially private sectors and the mainstream ELT is presented often without any sensitivity, criticism and resistance (Davari, 2011).

Encountering this situation, we strongly believe that since at present the current spread of English especially through ELT in Iranian society on the one hand, cannot be really halted and on the other hand, we do not dispute the importance of learning English in a globalizing world, it is suggested that applying CP in ELT not only can ameliorate the detrimental effects of English spread, but also it can manage this spread and also can adapt it to our society's needs and interests. In fact, following Canagarajah's (1999, p. 174) belief, we also maintain that "what is demand is a "third way" that avoids the traditional extremes of rejecting English outright for its linguistic imperialism or accepting its wholesale for its benefits".

Here, before dealing with the rationale for applying CP in ELT in Iranian society, it seems necessary to briefly introduce $\mathrm{CP}$ and its main features and components in more practical terms.

\section{A. What is $C P$ ?}

While, as Ford (2009) asserts the last few decades have seen a growing interest in CP in both ESL and EFL contexts, according to Akbari (2008b), in spite of the great potential of CP, the potential implications of CP have not been well 
appreciated and most of the reference to the term have been limited to its conceptual dimensions. Tackling this drawback, in this paper it has been attempted to introduce and highlight this approach in ELT in more practical terms.

In Pennycook's (1990) words, CP can be defined as an approach to teaching and curriculum that "seeks to understand and critique the historical and sociopolitical context of schooling and to develop pedagogical practices that aim not only to change the nature of schooling, but the wider society. According to Akbari (2008b), CP in ELT is an attitude to language teaching which relates the classroom context to the wider social context and aims at social transformation through education. Canagarajah (2005) introduces CP not as a theory, but a way of doing learning and teaching or borrowing Pennycook's (2001) terminology, it is teaching with an attitude. According to Byean (2011), in ELT, CP primarily prompts teachers to scrutinize English language in light of the historical, cultural, sociopolitical and economic issues. Given the complexity and the role of English, Norton and Toohey (2005) believe that CP asks teachers to surpass the view of English as "simply a means of expression or communication", but a practice that constructs the ways learners understand themselves, their sociohistorical surrounding and their possibility for the future. In Crookes and Lehner's (1998) words, CP in English should not be seen as a merely pedagogical method as to "how to teach English", but as a social and educational approach which is concerned about how English learning can affect personal and social change. In this sense, Byean (2001) maintains that in CP, English pedagogy should be focused on enriching not the English language, but the education of a country; in turn, CP values glocalized English pedagogies in conjunction with local educational context.

In fact, while as Byean (ibid.) asserts, in ELT, professionals have made less or no effort to raise the critical awareness toward English per se and the dominant principles in the ELT discipline have led ELT professionals to pay more attention to language teaching methodologies about what goes in the classroom in favor of an oversimplistic functionalist attitude toward the global spread of English as natural (a natural result of globalization), neutral (a neutral medium of communication with no cultural or political issues attached) and beneficial (a beneficial language since it improve international or intranational cooperation) (see, Pennycook, 1995), and the mainstream ELT mostly concerns specific strategies and techniques for achieving predetermined learning objectives in classroom, critical pedagogy involves all the aspects of educational practices in a society such as curriculum content and design, classroom teaching, technique and evaluation methods as well as historical, sociopolitical and cultural facets of a society. In more detail, it is noteworthy that contrary to the mainstream pedagogy in ELT which presents itself as a mere educational activity, publicizes native-based or the Inner-circle varieties of English especially the American and British ones, ignores or rejects World Englishes, introduces itself as the only legitimate reference of planning and producing methods, materials and programs and advertises the homogenization of cultural and educational goods influenced by global standardization carrying from the center to the periphery, critical pedagogy in ELT proposes that ELT functions as a vehicle for imposing western capitalist values and beliefs, questions the cultural and social relevance and appropriateness of innercircle produced methods and materials, focuses on the political, cultural, social, economic and ideological aspects of ELT, challenges the established and globally known tenets and bases of ELT and promotes itself as an alternative approach to the mainstream pedagogy in ELT.

Simply put, avoiding some usual conceptual dimensions and referring to the practical implications and features of CP, in the following firstly the contextual considerations of the Iranian society as the specific reference of this study is presented, then the main features of CP in ELT are introduced and the rationale for its applying in ELT in Iranian society is discussed.

\section{B. Contextual Considerations}

As Matsuda (2006) asserts, all pedagogical decisions need to be made taking into account the context in which the instruction take place and certainly providing a local perspective of English and ELT in Iran as well as a picture of the Iranian society itself in general seems necessary. Thus, in the following, such a picture is presented.

Islamic Republic of Iran, as a home to one of the world's oldest civilizations, is known as a developing country in the modern world. While the cultures of this society are fascinating and complex in their linguistic and ethnic diversity, the Islamic culture is more dominant. During the recent decades especially after the Islamic Revolution in 1979, this society has been experiencing a period of transition. Undergoing undeniable changes in different areas including social, political and cultural ones, changes in the system of education have also been significant.

Regarding the foreign language education also English has become synonymous with foreign language in Iran. Considering the status of English in Iran, Tollefson (1991) attempts to study its presence before and after the Iranian Islamic Revolution in 1979. In this regard, he writes that before the Iranian Revolution, English was widely taught and studied as part of country's push for modernization, in a way between the mid-1950s and late 1978, English steadily expanded at the most common second language in Iran and became the major language of business, the military, higher education, and the media. He believes that the fate of English after 1978-79 without a basic understanding of its role in Iran under the Shah is impossible. After studying the economic and political reasons as well as educational ones which led to accelerating the penetration of English in Iranian society, Tollefson tries to present a picture of English in Iran after the Islamic Revolution. In his words, the Revolution sought to nationalize the use of English. In addition, the end of modernization program began by the Shah meant that English was no longer the dominant language of business, government, the military, and industry. Thus, English was gradually restricted to areas in which it would be beneficial to newly defined Iranian interests like diplomacy and access to scientific literature. Tollefson believes that the end of 
English domination was associated with the changing structure of power in Iranian society. Moreover, he predicts that as long as the current political leadership dominates, the role of English is likely to remain limited. Beeman (1986) also, studying the position of English in two phases, namely before and after the Islamic Revolution, holds a similar position.

In spite of these views toward the role of English in Iranian society after the Islamic Revolution, it seems that the current status and position of this language have been significantly changed during the recent years, in a way that it has received particular attention. As Riazi (2005) writes, today a need for English language in Iran is obvious. Moreover, Talebinezhad and Aliakbari (2003) believe that English is going to become a necessity, rather than a mere school subject.

At present, English is the widely taught foreign language in Iran. Respecting the changes and the former and current status of ELT in Iran, Aliakbari (2002) writes that English language teaching in Iran has passed through a host of ups and downs and has experienced extreme courses. In his words, prior to the Islamic Revolution in 1979, because of the exceptional relations between the Iranian government and the West, especially the U.S. and England, English language teaching received particular attention. Vigorously strengthened by the presence of abundant native speaking teachers, and the contribution of several American and British institutions, the condition led to such an extreme position that certain national universities were conventionally called American Universities. Post-revolutionary reactions to ELT, in certain ways, went to extremes as well. Following the revolutionary oppositions against the U.S. as the main supporter of the fallen kingdom, and because of the perception of parallelism between English and the U.S., ELT received waves of hostility. A movement, generally referred to as ' book purging', aimed at 'de-culturalization' of school and university English-teaching textbooks. As an urgent reaction, certain words and concepts were replaced by 'proper' acultural or neutral ones. Replacing the national course-books and designing new materials were the next steps. The materials developed, then, generally represented the concepts, topics and ideas that Iranian students might learn in other courses including history and divinity. At present, in his words, the dominant trend in Iran is toward more English language teaching.

In Iranian educational system, while in the public sector, English is taught from junior high school as a compulsory school subject on the curriculum, it is taught in most of private primary schools and even at pre-school levels. Moreover, in higher education English has found an important status. But, in private sector, the changes have been more significant. Like many parts of the world, ELT is known as an important educational activity in private sector and also big business. Due to some limitations and drawbacks in state educational system, private language institutes have simply attracted an increasing number of learners. According to Talebinezhad and Sadeghi Beniss (2005), the deficiency of public schools and universities in satisfying students' ever-increasing desire to learn English communicatively has resulted in an extensive and still growing private sector of English teaching in Iran. In this regard, Riazi (2005) states that today in addition to formal private schools offering English language at different levels in their curriculum, there are plenty of private and semi-private English-language institutes and centers that offer courses at different levels and for different purposes. Looking at the methods, materials and assessments current in Iranian private sector reveals that the model of English to emulate tends to be mostly the Inner Circle varieties of English. For instance, the latest versions of wellknown educational books produced and published in Inner Circle, such as New Interchange, New Headway, Fundamentals, Impact, Gold, etc. are the main sources of English teaching in private sector. Along with their audiovisual aids, their teacher guides and achievement tests are mostly used. In this growing sector, English is mostly taught communicatively and the most important skill is speaking. In this sector, monolingual education is more dominant and native pronunciations, especially American pronunciation, are mostly followed. In all, the Inner Circle English enjoys the most important position in this EFL context.

Being familiar with these considerations, in the following the rationale for applying $\mathrm{CP}$ in this context is discussed:

\section{Socio-political and ideological factors}

As noted, the Iranian society as an Expanding Circle society is known as one whose dominant ideology is "antiimperialistic" and Islamic culture is predominant. During the recent decades, the Iranian government not only insists on rich cultural and social values, but has tried to announce its cultural and political independence more widely. Facing these facts, today as Phillipson (1992 and 2009) and Bourne (1996) maintain a very important aspect of the politics and economics of English is ELT and the spread of English especially through ELT has played a key role in the expansion of the cultural, economic and political influence of the Center in less developed countries or the Periphery especially in government and education, the Iranian language policy-makers should encounter English and ELT more consciously and critically. According to Phillipson, the high status of English in these two interrelated sectors perpetuate the dependency of the Periphery on the powerful Center countries and there interests. In such a situation, as Al-Issa (2006) writes, the less developed countries are the mere consumers of the expertise, methodology and materials dispensed by the West and according to Canagarajah (1999) such a transfer promotes Western ideologies and contribute to its domination more subtly. In this regard, Phillipson (1990) notes that ELT has been a means toward political and economic goals and a means of securing ties of all kinds with the Third World countries. Thus, it is not surprising to see that Dua (1994) writes that the USA looks at the promotion of English as one of its objectives of cultural policy and Pennycook (1994) introduces ELT as a fundamental component of the Center policy throughout the world.

Referring to this fact that the complexity resulting from the spread of English is not limited to its linguistic forms and functions, but has also found its political and ideological and poses a new set of questions about an aspect of ELT that 
has received only peripheral attention until recently, we should accept this fact that as Johnston (2003) asserts ELT undoubtedly is and always has been a profoundly and unavoidably political activity or as Phillipson (1992) notes ELT is a tool for the Center's imperialism or hegemony.

There is no doubt that the Iranian decision-makers and language policy makers and planners must consider such issues and do not see ELT as a value-free or a mere educational issue which is avoid of any sociopolitical factor. In this regard, findings of Davari (2011) also reveal that the Iranian ELT community believes that ELT is tied to the Western political system and it should be studied from a sociopolitical standpoint.

Currently, since the importance of English in the globalizing world is not deniable and the available evidence, as Ahmadipour (2008) notes, reveals that the Iranian language policy makers on the one hand attach importance to English language and on the other hand attend to its sociopolitical, cultural and ideological impacts, certainly the best and the most suitable approach to face English and ELT can be critical pedagogy which as mentioned chooses the 'third way" that avoids the traditional extremes of rejecting English outright for its linguistic imperialism or accepting its wholesale for its benefits. Thus, considering the socio-political and ideological dimensions and impacts of ELT, critical pedagogy which as Byean (2011) asserts clearly maintains that English teachers, being aware of the interlinked facets of English and its underlying ideologies in ELT, need to approach ELT with more critical minds, can be an alternative approach to the mainstream ELT which is mostly current in ELT profession in Iranian society.

\section{The issue of culture}

In Akbari's (2008b) words, culture has always been treated as an indispensable part of any language teaching/learning situation. From a broader perspective, according to Davari (2011) one of the most controversial facets of the globalization of English and ELT is the relationship between language and culture. In this regard, Wilson (2005) states that cultural homogenization or in many cases Americanization is a controversial aspect of globalization in ELT. While Crystal (1997) clearly asserts that different cultures throughout the world can exist along with the global spread of English, the scholars belonging to CP tradition including Phillipson (1992), Pennycook (1994, 2001 and 2007), Alptekin (2002) and Canagarajah (1999) maintain that the spread of English threatens different cultures in the world. Alptekin (2002) believes that ELT is "enculturation" in which the learner acquires new cultural frames of reference and a new worldview, reflecting those of the target language culture of its speakers. Canagarajah (1999) also demonstrates the cultural load of ELT practices developed in the Center. In this regard, he maintains that English spread especially through ELT strengthens the cultural hegemony of the Center. Moreover, Pennycook (2007) introduces the impact of English culture so great that clearly asserts that we must rethink the relationship between English, pedagogy and culture within the contemporary world.

Focusing on the position and impact of culture, Fredricks (2007, p. 22) writes that "as EFL programs become more prevalent throughout the world, the cultural imperialism of English teaching are more often debated." In her words, these cultural considerations are extremely relevant in Islamic cultures, where English education can be viewed as contributing to the influence of western Christian or secular pedagogy. According to Pennycook (1994) the kinds of knowledge and cultures to which English is strongly associated clash with or even threaten an Islamic worldview, culture and lifestyle. For example, studying the cultural content of the teaching materials used in Iranian society even those developed locally indicates that most cultural content however has been from the target culture.

Currently, observing the English language classes shows that they often incorporate the teaching of culture as part of their content. Sometimes, cultural topics are there merely to give the classes something to read, write, listen to and talk about in the target language and other times, learning culture is one of the explicit goals of an English language curriculum. For example, teaching some books such as Impact series can be introduced as a significant case of learning culture rather than language.

Regarding this situation, the main justification has been that those who want to learn English want to communicate with the users of this language, and successful communication would not be possible without the learners' familiarity with the cultural norms of English speakers. In this case, Akbari (2008b) insists on this fact that this assumption is only true for those who want to migrate to countries such as the US or UK for work or study. Moreover, in his words, due to the scope of English application both geographically and communicatively, most of the communication carried out in English is between people who are themselves the so-called non-native speakers of English with a distinct cultural identity of their own. Thus, there is little need in this context for the Anglo-American culture, since neither party is a native with whom the other interlocutor is going to identify.

Encountering these facts, there is no room to doubt that $\mathrm{CP}$ as an educational approach which shows sensitivity to the issue of culture and does not see ELT as a value-free profession, can be an alternative approach in EFL contexts especially in societies like Iran whose cultural and religious values are different from the Center.

\section{Local as well as global topics}

As Bardovi-Harling (1996) notes, teaching materials, especially textbooks, are perceived as a prestige source of input and play an important part in curriculum design of a foreign language class, because learners especially in EFL contexts do not receive much input outside the classroom.

Reviewing the topics of the current ELT textbooks indicates that most of the topics in these books are either Centeroriented or sanitized. Concerning the Center-oriented textbooks, Gray (2000) maintains that it is precisely the ambassadorial aspect of the ELT couresbooks which has led to recent criticisms. Phillipson (1992) also sees the 
promotion of such global couresbooks as a government-backed enterprise with an economic and ideological agenda aims ultimately at boosting commerce and the dissemination of ideas.

Studying the topics of some current textbooks used in Morroco, Sellami (2006) reveals that the topics and the content of such Center-oriented couresbooks are in sharp contrast with an Arab and Islamic culture.

Gray (2002) also maintains that one effect of globalization is the imposition of Center materials on the Periphery in the increasing spread of global ELT couresbooks which are thematically and culturally "inclusive" and "inappropriate". In this regard, Canagarajah (1999) demonstrates such a lack of appropriateness in this way: "The Tamil students sit listening to the teacher reads about the life of a middle-class British university student, while Government helicopters fly above searching for Tamil tigers. The textbooks could not move detached from the students' lives" (p. 10). According to Banegas (2010), such couresbooks are criticized not only for avoiding provoking topics, but also for presenting a romantic view of countries such as Britain or the USA. In his words, in an attempt to avoid some controversial and real issues, material writers opt for selecting themes that are rooted in the British or American culture. Gray (2000) writes that topics are chosen in such a way that the target culture seems to uphold values and living standards that are better than those of the student's culture, leading to the perception that the target culture is superior to the student's. Even if textbooks do contemplate topics such as poverty, hunger, or even discrimination, they are contextualized in Africa or the Muslim world, creating the idea that poverty or discrimination is nowhere to be found in Europe or the USA.

Raising such sensitivities to such textbooks and even setting aside some Center-oriented textbooks in some educational systems, have led to developing some new famous textbooks which are mostly sanitized and neutralized (Gray, 2001). In this regard, Akbari (2008c) states that many of the textbooks are sanitized and neutralized "to make sure they do not lose their market potential and in this process most of the topics of interest for a critical pedagogy are removed. In his terms, most of the topics one encounters in commercially prepared textbooks deal with harmless issues such as travel, shopping, holidays and food recipes, leaving little room for social transformation and political awareness rising." Hillyard (2005) points out that when we study the topics of such textbooks, there is little controversial material. On the contrary, we find themes such as the family, sport, hobbies, travel, pop culture, festivals from remote countries which bear no impact on students' lives, fashion and food, among others. Also according to Banegas (2010) recently for reasons generally attributed to the production and matching of mainstream couresbooks produced for the general EFL class regardless of where they are used, publishers avoid the inclusion of provocative topics in developing the units of work couresbooks may be divided into.

In $\mathrm{CP}$, what is more essential for both teachers and students are being critically aware of issues surrounding them both locally and globally (Byean, 2011). According to Akbari (2008b) CP takes the local as its point of departure and local here includes the overall actual life experiences and needs of learners. Akbari believes that a problem of commercially produced couresbooks is their disregard for the local issues or in a more precise word, their real-life concerns. In his belief, from a critical perspective, reliance on one's own local culture has the added value of enabling learners to think about the different aspects of the culture in which they live and find ways of bring about changes in the society where change is needed. If students are going to transform the lives of themselves and those of others, they cannot do so unless due attention is paid to their own culture in the curriculum and opportunities are provided for crucial reflection on its features. Akbari also writes that reliance on learners' culture as the point of departure for language teaching will make them critically aware and respectful of their own culture and prevent the development of a sense of inferiority which might result from a total reliance on the target language culture where only the praiseworthy features of the culture are presented. Criticizing such topics presented in the mainstream textbooks, Banegas (2010) supports $\mathrm{CP}$ as an approach which critical teachers are empowered so that they can reject, criticize and adapt the material they use in order to help their students develop their cultural thinking skills.

In addition to local topics, CP insists that global issues should be incorporated in ELT. In Sampedro and Hillyard' $\mathrm{s}$ (2004) terms, global issues can no longer be dismissed as the "out there", but they are very much "in here" too and can no longer be safely ignored. Matsuda (2006) points out since at present learners want to become effective users of English in the international context, some awareness of global cultures and issues needs to be fostered. In her words, such topics as world peace, environmental conservation and other relevant topics in the field of global education provide appropriate content for readings, class discussions and course assignments.

According to Gursoy and Saglam (2011), since critical pedagogy turns attention towards the relationship between the society and school, language educators feel the need to combine educational goals with social and global responsibilities. Arikan (2009) maintains that global issues and their use in foreign language teaching are considered very relevant as newer approaches examining the learners within their social and natural environment. Brown (1997) also attempts to offer a rationale for giving learners of English language an opportunity to engage in critical thinking on questions of global importance. In Byean's (2011) words, CP aims at raising students' critical reflections on local and global problematic issues.

Since $\mathrm{CP}$, insisting on improving critical thinking, aims to empower language learners and provides an opportunity for the learners to transform their lives, on the one hand, it is strongly suggested that the topics and content of textbooks, class discussions and course assignments are contextually and locally situated and on the other hand to be effective users of English in the global context, integrating global issues needs to be fostered. According to Rashidi and Safari 
(2011), for CP to be truly effective in an English language program, materials should simultaneously develop learners' language skills and their awareness of the social structures. Concerning the Iranian society also findings of Davari (2011) reveal that the Iranian ELT community believes that learners' interests and their life experiences can be a valuable choice for the starting point in ELT.

Thus, avoiding the Center-oriented or sanitized textbooks as well as considering this fact that raising learners' critical consciousness to be aware of their sociopolitical surroundings in the globalizing world is an object of the education for the Iranian society, incorporating local as well as global issues in ELT can meet this need.

\section{CONCLUSION}

This study, considering the contextual considerations of the Iranian society as an Expanding Circle country, tried to introduce and discuss the rationale of applying $\mathrm{CP}$ as an alternative and effective approach in ELT. Although other factors including the potential use of mother tongue, native speaker fallacy/tenet, teaching methods, etc. can be also dealt with, only three factors of (a) socio-political and ideological factors, (b) the issue of culture, (c) local as well as global topics were discussed in more details. Considering these factors, it is believed that applying this critical approach can meet not only the goals of the Iranian educational system, but also can meet the Iranian EFL learners' needs and interests. Accepting this given that the emergence of English as a global language is going to seriously influence language planning and policy making in every society (Nunan, 2003), it is essential for us to adopt a more dynamic, critical and conscious position toward this trend. In this regard, encountering this trend critically involves firstly doubting what is taken for granted by the mainstream ELT and seeing English and ELT through a broader sociopolitical and cultural perspective. Reviewing the features of CP reveals that undoubtedly this approach enjoying these criteria might be the best choice for such a society.

\section{REFERENCES}

[1] Ahmadipour, T. (2008). The necessity of adopting an appropriate language policy against the spread of English language. National Studies Quarterly, 9 (3), 119-134.

[2] Akbari, R. (2008a). Education is filled with politics. ELT journal, 62(3), 292-293.

[3] Akbari, R. (2008b). Transforming lives: introducing critical pedagogy into ELT classrooms. ELT Journal, 62(3), $276-283$.

[4] Akbari, R. (2008c). Postmethod discourse and practice. TESOL Quarterly, 42(2), 641-652.

[5] Aliakbari, M. (2002). Culture in language teaching. Unpublished Ph.D. dissertation, University of Isfahan.

[6] Al-Issa, A. (2006). The cultural and economic politics of ELT in Sultanate Oman, 8 (1), 194- 218.

[7] Alptekin, C. (2002). Toward intercultural communicative competence. ELT journal, 56(1), 57-64.

[8] Anderson, C. (2003). Phillipson's children. Language and Intercultural Communication. 3 (1), 81-95. [1]

[9] Arikan, A. (2009). Environmental peace education in foreign language learners' English grammar lessons. Journal of Peace Education, 6, (1), 87-99.

[10] Baladi, N. (2007). Critical Pedagogy in the ELT Industry: Can a Socially Responsible Curriculum Find its Place in a Corporate Culture? Unpublished MA Thesis, McGill University.

[11] Banegas, D. L. (2010). Teaching more than English in secondary education. ELT Journal, 65(1), 80-82.

[12] Bardovi-Harling, K. (1996). Pragmatics and language learning: bringing pragmatics and pedagogy together. Pragmatics and Language Learning, 7, 21-38.

[13] Beeman, W. O. (1986). Language, Status and Power in Iran, Bloomington: Indian University Press.

[14] Block, D. and Cameron, D. (Eds.) (2002). Globalization and Language Teaching. London: Routledge.

[15] Bourne, J. (1996). English for the speakers of other languages. In N. Mercer and J. Swann (Eds.), Learning English: Development and Diversity (pp. 243-270), London: Routledge.

[16] Brown, H. D. (1997). The place of moral and political issues in language pedagogy, Asian Journal of English Language Teaching, 7, 21-33.

[17] Brutt-Griffler, J. (2002). World English: A Study of its Development. Clevedon: Multilingual Matters Ltd.

[18] Byean, H. (2011). An Exploration for Glocalizing Critical Pedagogy in the Korean Middle School Context: Toward Critical Co-teaching Praxis between Local and Native-English-Speaking Teachers, Unpublished Ph.D. dissertation, University of Wisconsin.

[19] Byram, M. \& Feng, A. (2004). Culture and language learning: teaching research and scholarship. Language Teaching 37(3): 149-168.

[20] Canagarajah, A. S. (1999). Resisting Linguistic Imperialism in English Teaching. Oxford: Oxford University Press.

[21] Cnagarajah, S. (2005). Critical pedagogy in L2 learning and teaching. In E. Hinkel (ed.). Handbook of Research in Second Language Teaching and Learning. Mahwah, NJ: Lawrence Erlbaum Associates.

[22] Crookes, G. and Lehner, A. (1998). Aspects of Process in an ESL Critical Pedagogy Teacher. Education Course. TESOL Quarterly 32(2), 319-328.

[23] Crystal, D. (1997). English as a Global Language. Cambridge: Cambridge University Press.

[24] Davari, H. (2011). Linguistic Imperialism or Global Understanding: ELT in Globalization from an Iranian Perspective. Unpublished MA thesis, Tarbiat Modares University.

[25] Dua, H. (1994). Hegemony of English. Maysore: Yashoda Publications.

[26] Edge, J. (Ed.) (2006). (Re)locating TESOL in an Age of Empire. London: Palgrave.

[27] Ford, K. (2009). Principles and practices of L1/L2 in the Japanese University EFL classrooms. JALT journal, 31(1), 63-80.

[28] Fredricks, L. (2007). A Rationale for Critical Pedagogy in EFL: The Case of Tajikistan. The Reading Matrix 7.2 , 22-28. 
[29] Gray, J. (2000). The ELT coursebook as cultural artifact: how teachers censor and adapt. ELT Journal. 54(3), $244-253$.

[30] Gray, J. (2002). The global coursebook in English language teaching. In D. Block and D. Cameron (Eds), Globalization and Language Teaching (pp. 151-167). London: Routledge.

[31] Gursoy and Saglam. (2011). ELT teacher trainees' attitudes towards environmental education and their tendency to use them in teaching. The 2011 Bacelonea European Academic Conference, Barcelona, Spain.

[32] Hall, G. (2000). Local approaches to Critical Pedagogy: An Investigation into the dilemmas raised by critical approaches to ELT. CRILE Publications, Linguistics Department, Lancaster University.

[33] Hillyard, S. (2005). Content with your content? Why teach Global Issues in ELT? In L. Angada (Ed.), $30^{\text {th }}$ FAAPI Conference, Towards the Knowledge Society: Making EFL Education Relevant. Conference Proceedings, Cordoba, Argentina: Comunicarte.

[34] Holborrow, M.(1999). The Politics of English: a Marxist view of language. London: Sage.

[35] Holliday, A. (1994). Appropriate Methodology and Social Context. Cambridge: Cambridge University Press.

[36] Holliday, A. (1997). The politics of participation in international English language education. System, 25, 409-423.

[37] Holliday, A. (2005). The Struggle to Teach English as an International Language. Oxford: Oxford University Press.

[38] Johnston, B. (2003). Values in English Language Teaching. Mahawah, NJ: Lawrence Erlbaum Association.

[39] Matsuda, A. (2006). Negotiating ELT assumptions in EIL classrooms. In J. Edge (Ed.). (Re)Locating TESOL in an Age of Empire (pp.158-170). London: Palgrave.

[40] Norton, B. and Toohey, K. (2004).Critical Pedagogies and Language Learning. New York: Cambridge University.

[41] Nunan, D. (2003). The impact of English as a global language on educational policies and practices in the Asia-Pacific region. TESOL Quarterly, 37(4), 589-613.

[42] Pennycook, A. (1990). Towards a critical applied linguistics for the 1990s." Issues in Applied Linguistics, 8-28.

[43] Pennycook, A. (1994). The Cultural Politics of English as an International Language. Essex: Longman Group Ltd.

[44] Pennycook, A. (1995). English in the world/The world in English. In J. Tollesfson (Ed.), Power and Inequality in Language Education (pp. 34-58). New York: Cambridge University Press.

[45] Pennycook, A. (1998). English and the Discourse of Colonialism. London: Routledge.

[46] Pennycook, A. (1999). Introduction: critical approaches to TESOL. TESOL Quarterly, 33, 329-348.

[47] Pennycook, A. (2001). Critical Applied Linguistics: A Critical Introduction. Mahawah, NI: Lawrence Erlbaum Associates.

[48] Pennycook. A. (2007). ELT and colonialism. In J. Cummins and C. Davison (Eds.) International Handbook of English Language Teaching. (pp. 13-24). Springer.

[49] Phillipson, R. (1992). Linguistic Imperialism. Oxford, Oxford University Press.

[50] Phillipson, R. (2009). Linguistic Imperialism Continued, London: Routledge.

[51] Rashidi, N. and Safari, F. (2011). A model for EFL materials development within the framework of critical pedagogy (CP), English Language Teaching, 4 (2), 250-259.

[52] Riazi, A. (2005). The four language stages in the history of Iran. In A. Lin and P. Martin (Eds.), Decolonization, Globalisation: Language-in-education Policy and Practice (pp.98-115). Clevendon: Multilingual Matters.

[53] Sadeghi, S. (2005). Critical pedagogy in an EFL teaching context: an ignis fatuus or an alternative approach? Journal of Critical Education Policy Studies, 6(1),1-9.

[54] Sampedro, R. and Hillyard, H. (2004). Global Issues. Oxford: Oxford University Press.

[55] Sellami, A. (2006). Slaves of sex, money and alcohol, (Re) locating the Target Culture of TESOL. In J. Edge, (Re) locating TESOL in an age of Empire. (pp. 177-194), London: Palgrave.

[56] Sharifian, F. (Ed.) (2009). English as an International Language: Perspective and Pedagogical Issues. Clevedon: Multilingual Matters.

[57] Skutnabb-Kangas, T. (1998). Human rights and language wrongs- a future for diversity? Language Sciences, 20, 5-28.

[58] Talebinezhad, M. R. and Sadeghi Beniss, A. R. (2005). Non-academic L2 users: a neglected research pool in ELT in Iran, Linguistik online, 25 (4), 85-96.

[59] Tollefson, J. W. (Ed.) (1995). Power and Inequality in Language Education. Cambridge: Cambridge University Press.

[60] Tsuda, Y. (1997). Hegemony of English vs. ecology of language: Building equity in international communication. In L. E. Smith and M. L. Forman (Eds.), World Englishes 2000: Selected Essays (pp. 171-182). Honolulu, HI: College of Language, Linguistics and Literature, University of Hawaii and the East-West Center.

[61] Wilson, R. (2005). Imposition or Adoption? The Globalization of ELT Practices. Unpublished MA assignment. University of Essex.

Ferdows Aghagolzadeh received his MA in linguistics in 1994 from Tarbiat Modares University (TMU), Tehran, Iran, and his $\mathrm{PhD}$ in 2002 from TMU. He is currently an associate professor and the head of Linguistics Department at TMU. His interests are discourse analysis, pragmatics and applied linguistics. He is the author of two books and has published and presented papers in these areas.

Hossein Davari received his MA in linguistics in 2005 from Tarbiat Modares University (TMU), Tehran, Iran, and his MA in TEFL in 2011 from Payame Nour University (PNU). He is a lecturer of PNU, Damghan, Iran. His interests include sociolinguistics, materials development, lexicography and ESP and has published and presented papers in these areas. 